\title{
Mode of Action, Metabolism, and Uptake of BAS 125W, Prohexadione-calcium
}

\author{
J.R. Evans ${ }^{1}$, R.R. Evans, and C.L. Regusci \\ BASF Corporation, 26 Davis Drive, Research Triangle Park, NC 27709 \\ W. Rademacher \\ BASF Agricultural Center, P.O. Box 120, 67114 Limburgerhof, Germany
}

\section{INTRODUCTION}

BAS 125W (trade name Apoge $\mathrm{e}^{\mathrm{TM}}$ ) is the experimental code for the plant growth regulator prohexadione-calcium (common name proposed to International Organization for Standardization), or prohexadione-Ca in short, or calcium 3-oxido-4-propionyl-5-oxo-3cyclohexene-carboxylate as a systematic chemical name (Fig. 1). Other codes for this active ingredient include BX-112, KIM 112, and BAS $9054 \mathrm{~W}$. The active ingredient, prohexadione-calcium, is patented by Kumiai Chemical Industry Co., which has registered it for growth control in rice (Oryza sativa L.) in Japan. Prohexadionecalcium is being developed for registration in the United States for use on apples (Malus $\times$ domestica Borkh.) and peanuts (Arachis hypogaea L.) by the BASF Corp., and in several European countries by BASF AG for use on small grains and apples.

Foliar application of BAS $125 \mathrm{~W}$ at rates of 125 to $250 \mathrm{mg} \cdot \mathrm{L}^{-1}$ a.i. has typically provided effective control of vegetative growth of apple trees. Generally, as the vegetative vigor of a tree increases, the rate of prohexadione-calcium needed for effective vegetative control has to be raised. Vegetative vigor is influenced by numerous factors, including fruit load, location, variety, rootstock, age, pruning, and training system. Applying prohexadione-calcium when new shoot growth is between 5 to $10 \mathrm{~cm}$ has provided more effective control of vegetative growth relative than has application after new shoot growth has

Received for publication 14 June 1998. Accepted for publication 1 Aug. 1998. The cost of publishing this paper was defrayed in part by the payment of page charges. Under postal regulations, this paper therefore must be hereby marked advertisement solely to indicate this fact.

${ }^{1}$ To whom reprint requests should be addressed. E-mail: evansj@basf.com exceeded $10 \mathrm{~cm}$. Because of its short-term effect and lack of persistence, prohexadione-calcium can be a flexible tool in developing userspecific growth management strategies.

\section{MODE OF ACTION}

Prohexadione-calcium inhibits the biosynthesis of growth active gibberellins (GAs), thereby reducing longitudinal shoot growth. The structure of prohexadione is similar to that of 2-oxoglutaric acid, which is the co-substrate for dioxygenases catalyzing hydroxylations involved in late stages of GA biosynthesis. The primary target of prohexadione-calcium seems to be $3 B$ hydroxylation. As a consequence, its application reduces levels of $\mathrm{GA}_{1}$ (highly active) and causes accumulation of its immediate precursor, $\mathrm{GA}_{20}$ (inactive) (Fig. 2). For details see Brown et al. (1997), Griggs et al. (1991), Hedden and

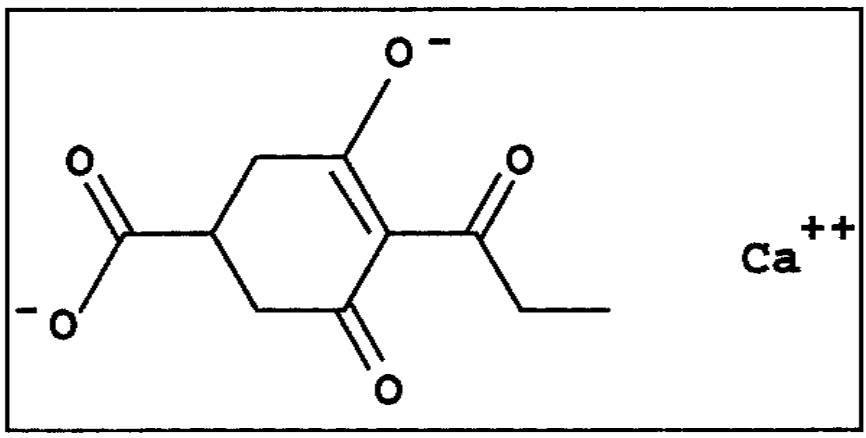

Fig. 1. Structure of prohexadione-calcium. 


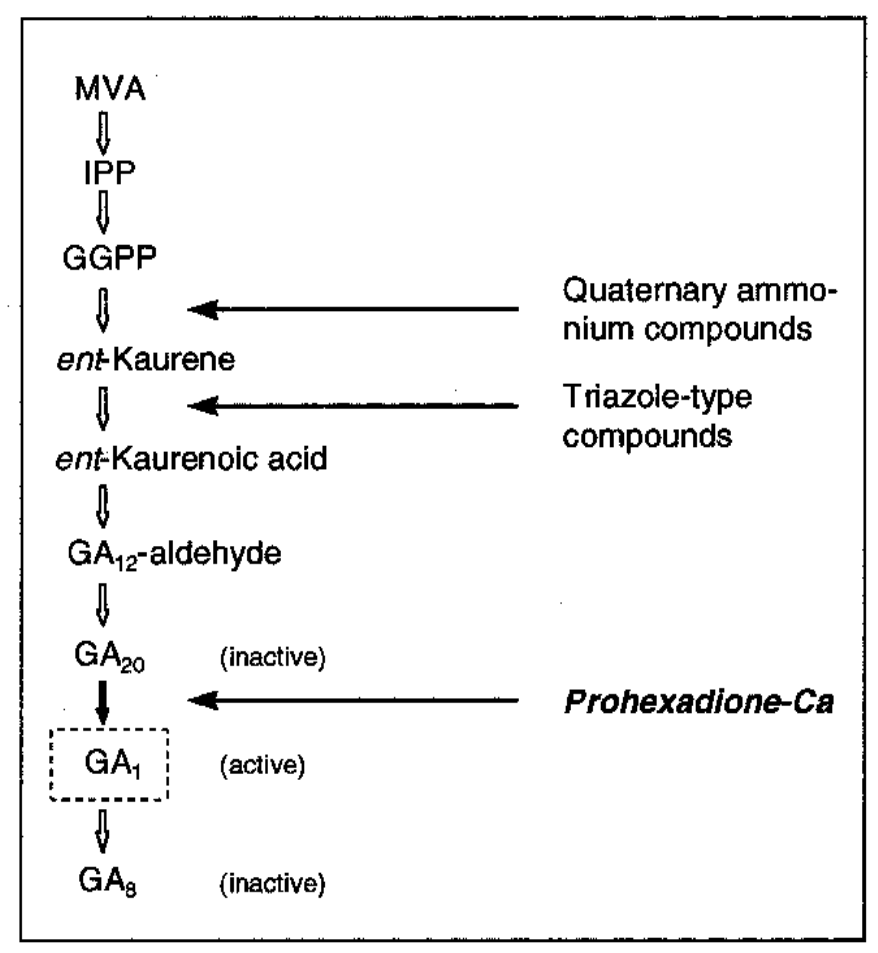

Fig. 2. Simplified scheme of GA biosynthesis and main point of inhibition by prohexadione-calcium $(\mathrm{MVA}=$ mevalonic acid, IPP $=$ isopentenylsphosphate, GGPP = geranylgeranylbisphosphate).

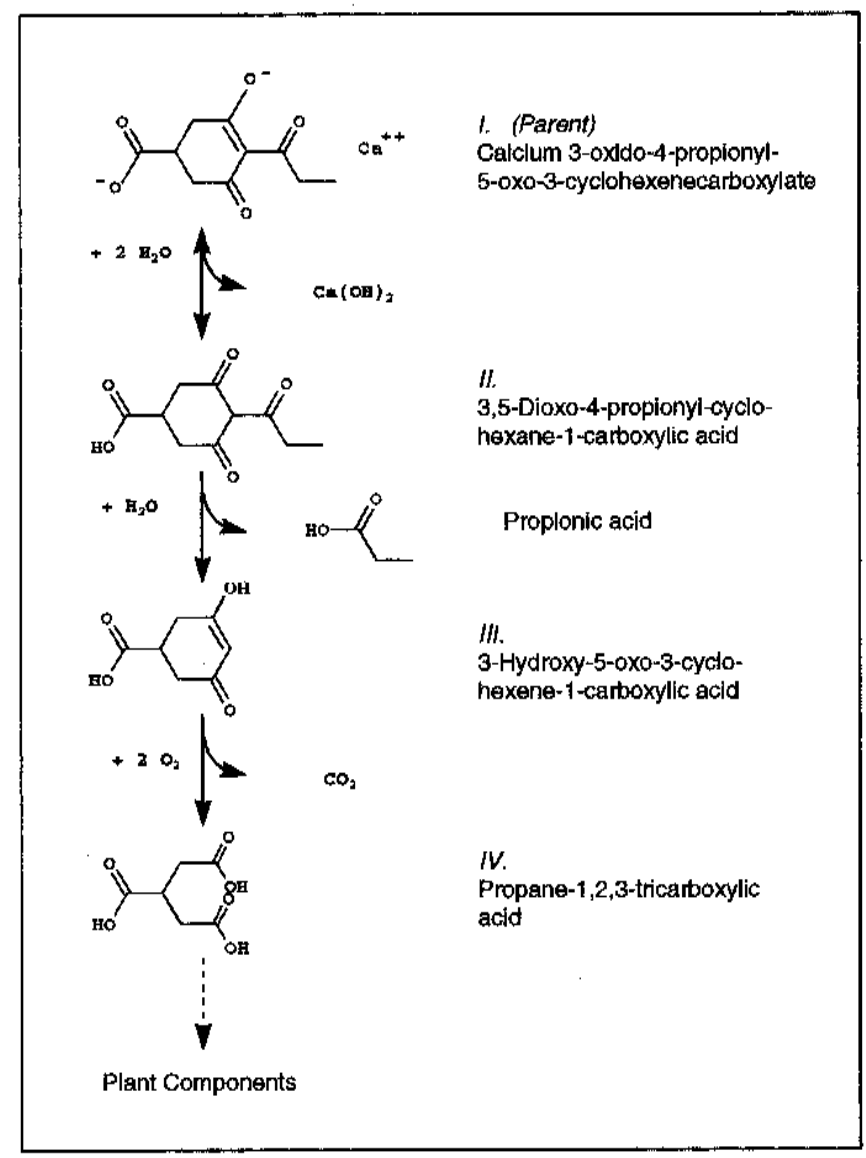

Fig. 3. Metabolism of prohexadione-calcium in higher plants.
Kamiya (1997), Nakayama et al. (1990a, 1990b), and Rademacher et al. (1992). Related dioxygenases involved in flavonoid metabolism may also be affected to some extent by prohexadione-calcium and related compounds (Rademacher et al., 1992).

\section{METABOLISM}

Prohexadione-calcium degrades in higher plants with a half life time of a few weeks. After deacylation and ring cleavage the naturally occurring propane-1,2,3-tricarboxylic acid (tricarballylic acid) is formed, which is incorporated into the plant matrix (cf. Fig. 3). In soil, prohexadione-calcium decomposes, mostly to carbon dioxide, with a half life of $<7 \mathrm{~d}$. In water, prohexadione-calcium degrades by photolysis to carbon dioxide and other natural products. In mammals, prohexadione-calcium is rapidly absorbed and then excreted. Accumulation in tissues of mammals has not been observed.

\section{TOXICOLOGICAL AND ECOTOXICOLOGICAL PROPERTIES}

Prohexadione-calcium has an acute rat oral $\mathrm{LD}_{50}>5000 \mathrm{mg} \cdot \mathrm{kg}^{-1}$ and an acute rat dermal $\mathrm{LD}_{50}>2000 \mathrm{mg} \cdot \mathrm{kg}^{-1}$. The material is not mutagenic, carcinogenic, or teratogenic. Prohexadione-calcium has no negative effects on birds, fish, honey bees (Apis mellifera L.), or soil micro-organisms.

\section{UPTAKE AND TRANSLOCATION}

Prohexadione-calcium is absorbed by apple foliage, maximum uptake requiring a minimum of $8 \mathrm{~h}$, and is translocated acropetally to the growing points of individual shoots. Basipetal movement is minimal. Typically, only the growth of treated shoots is affected. Prohexadione-calcium does not persist in the plant or directly affect vegetative growth the following season.

\section{Literature Cited}

Brown, R.G.S., H. Kawaide, Y.Y. Yang, W. Rademacher, and Y. Kamiya. 1997. Daminozide and prohexadione have similar modes of action as inhibitors of the late stages of gibberellin metabolism. Physiol. Plant. 101:309-313.

Griggs, D.L., P. Hedden, K.E. Temple-Smith, and W. Rademacher. 1991. Inhibition of gibberellin 2ß-hydroxylases by acylcyclohexanedione derivatives. Phytochemistry 30:2513-2517.

Hedden, P. and Y. Kamiya. 1997. Gibberellin biosynthesis: Enzymes, genes and their regulation. 1997. Annu. Rev. Plant Physiol. Plant Mol. Biol. 48:431-460.

Nakayama, I., Y. Kamiya, M. Kobayashi, H. Abe, and A. Sakurai. 1990b. Effects of a plant growth regulator, prohexadione, on the biosynthesis of gibberellins in cell-free systems derived from immature seeds. Plant Cell Physiol. 31:1183-1190.

Nakayama, I., T. Miyazawa, M. Kobayashi, Y. Kamiya, H. Abe, and A. Sakurai.1990a. Effects of a new plant growth regulator prohexadione calcium (BX-112) on shoot elongation caused by exogenously applied gibberellins in rice (Oryza sativa L.) seedlings. Plant Cell Physiol. 31:195200.

Rademacher, W., K.E. Temple-Smith, D.L. Griggs, and P. Hedden. 1992. The mode of action of acylcyclohexanediones-A new type of growth retardant, p. 571-577. In: C.M. Karssen, L.C. van Loon, and D. Vreugdenhil (eds.). Progress in plant growth regulation. Kluwer Academic, The Netherlands. 